\title{
Bahiagrass for Florida Lawns ${ }^{1}$
}

\section{Laurie E. Trenholm, Marco Schiavon, J. Bryan Unruh, Travis W. Shaddox, and Kevin E. Kenworthy ${ }^{2}$}

Bahiagrass (Paspalum notatum Flugge) was introduced from Brazil in 1914. It was originally used as a pasture grass on the sandy soils of the southeastern United States. Additional varieties have been introduced since that time for use as lawn grasses. Bahiagrass is a low-maintenance lawn grass that does well with limited water and fertilizer inputs. Varieties currently available do not produce a carpet-like, dense lawn like some other warm-season lawn grasses. This publication is intended for homeowners and turfgrass managers that manage bahiagrass in the state of Florida.

\section{Characteristics}

Bahiagrass forms an extensive, deep root system. It persists better than other grasses in infertile, sandy soils and does not require high inputs of water or fertilizer. For these reasons, it is the dominant forage used in pastures throughout Florida and why it is a good choice for home sites on large lots or acreage or for anywhere without an irrigation system. It should be noted that during extended drought periods, bahiagrass will go into a drought-induced dormancy and turn brown until conditions become favorable for regrowth.

Bahiagrass can be found throughout the state but prefers acidic soils. It does not form excessive thatch. It may be grown from seed, which is abundant and relatively inexpensive, but may take some time to germinate and provide cover. It may also be established from sod. If left unmowed, bahiagrass can reseed itself from the seed heads that it produces, especially during the long days of summer (Figure 2). It has relatively few disease and insect problems.

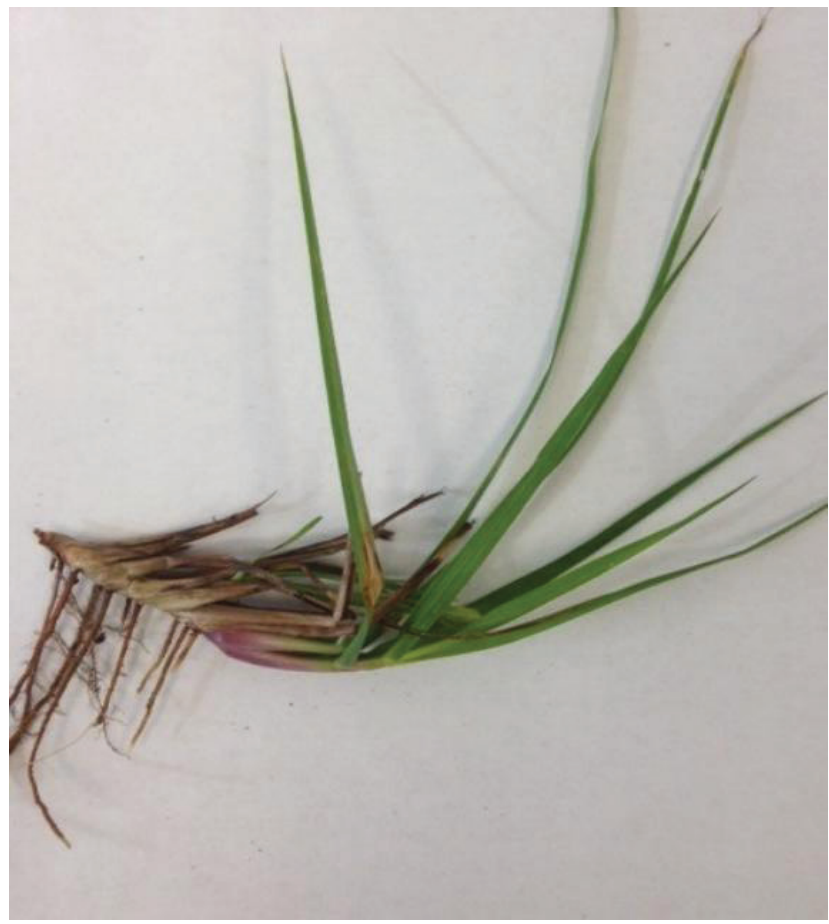

Figure 1. Bahiagrass sprig.

Credits: L. Trenholm, UF/IFAS

1. This document is ENH6, one of a series of the Environmental Horticulture Department, UF/IFAS Extension. Original publication date May 1991. Revised October 2000, August 2003, April 2011, November 2015, January 2018, and February 2022. Visit the EDIS website at https://edis.ifas.ufl.edu for the currently supported version of this publication.

2. Laurie E. Trenholm, retired professor, turfgrass specialist, Environmental Horticulture Department; Marco Schiavon, assistant professor, turf and sod, Environmental Horticulture Department, UF/IFAS Ft. Lauderdale Research and Education Center; J. Bryan Unruh, professor and associate center director, Environmental Horticulture Department, UF/IFAS West Florida REC; Travis W. Shaddox, former assistant professor of turfgrass, Environmental Horticulture Department, UF/IFAS Ft. Lauderdale REC; and Kevin E. Kenworthy, professor, plant breeding and molecular genetics, Agronomy Department; UF/IFAS Extension, Gainesville, FL 32611.

The Institute of Food and Agricultural Sciences (IFAS) is an Equal Opportunity Institution authorized to provide research, educational information and other services

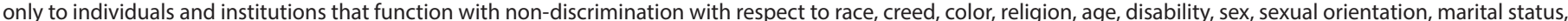
national origin, political opinions or affiliations. For more information on obtaining other UF/IFAS Extension publications, contact your county's UF/IFAS Extension office. U.S. Department of Agriculture, UF/IFAS Extension Service, University of Florida, IFAS, Florida A \& M University Cooperative Extension Program, and Boards of County Commissioners Cooperating. Andra Johnson, dean for UF/IFAS Extension. 


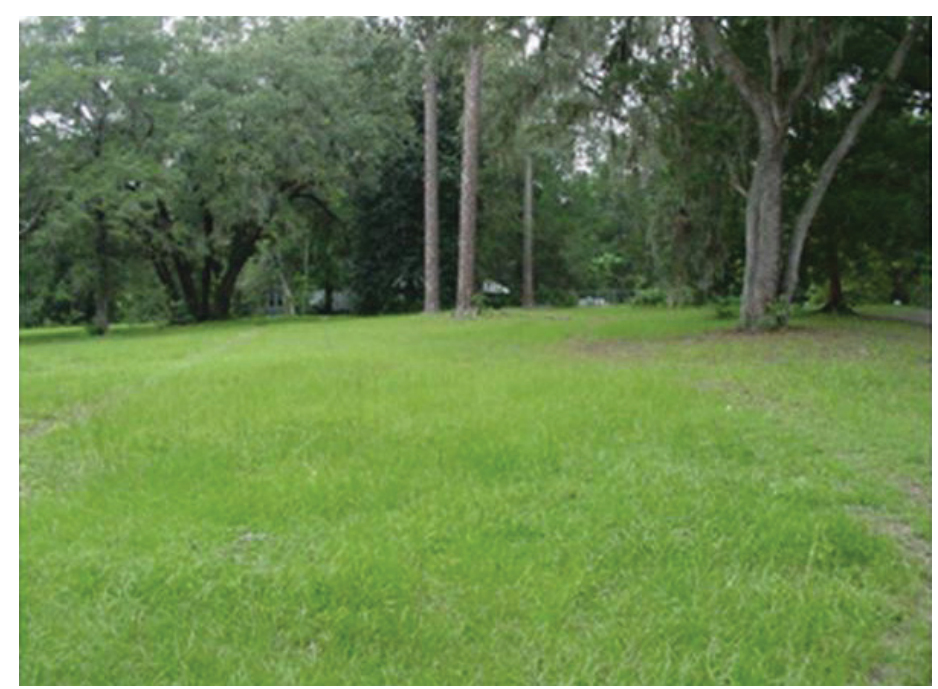

Figure 2. A low-maintenance bahiagrass lawn with seed heads visible. Credits: L. Buss, UF/IFAS

\section{Varieties}

\section{'Common'}

'Common' bahiagrass is a coarse-textured, light-colored bahiagrass. It has an open and sparse growth habit and is very susceptible to cold temperatures. It is not normally recommended for use as a lawn grass.

\section{'Argentine'}

'Argentine' forms a relatively dense sod and has a dark green color, making it acceptable for lawn use in many situations. It has wider leaf blades than 'Pensacola' bahiagrass. It has good insect and disease resistance and tolerates cold temperatures well. While still tall, seed heads of Argentine are slightly shorter and less dense than Pensacola seed heads. Argentine produces seed through apomixes, which means that each seed is genetically identical and identical to the maternal plant. Therefore, a stand of Argentine seedlings will produce a highly uniform turfgrass area. For these reasons, Argentine is typically preferred for turf use compared to Pensacola. Argentine has a shorter growing season than Pensacola. When exposed to cooler temperatures, it will lose color sooner than Pensacola.

\section{'Pensacola'}

'Pensacola' bahiagrass was selected in Pensacola, Florida, in 1935 and is the most widely grown bahiagrass in pastures. It has an extensive root system, which imparts excellent stress tolerance. It tolerates both hot and cold temperatures well. It produces more seed heads than 'Argentine', which reduces its desirability for use as a lawn grass but makes it suitable for roadside plantings. It has longer and narrower leaf blades than 'Argentine'. Pensacola hold color and resists winter dormancy better than other bahiagrasses. Pensacola seed are produced through sexual recombination. Therefore, each seed is genetically related but different. Seedlings can vary slightly in appearance creating a less uniform stand compared to Argentine.

\section{Establishment of Bahiagrass}

Bahiagrass can be established from sod or seed. Advantages of planting from sod are rapid establishment of the lawn and fewer opportunities for weeds to invade. Most bahiagrass sod is harvested from pastures and may contain difficult to control weeds. Consequently, it is a good practice to inspect the sod before agreeing to accept it. Additionally, bahiagrass generally does not form uniform sod slabs like most other turfgrasses. Sometimes, the sod falls apart upon installation. Surprisingly, the small pieces will become established in time. On larger jobs, the bahiagrass comes in large rolls with a netting material that aids in keeping the sod together. The primary disadvantages of this method are the expense and labor required to lay the sod. In contrast, seeding is less expensive and requires less labor than sodding, but bahiagrass seed germinates slowly and takes longer to form a uniform turf cover. Water, either from rainfall or from irrigation, helps promote faster germination of bahiagrass seed and improves the odds of successful establishment. Scarified seed, which has been chemically treated to enable faster germination, should be used when available. Note that sod production fields of bahiagrass are planted from seed.

Plugging or sprigging bahiagrass is not typically recommended. Because of the slow growth habit of bahiagrass, the plugging method leaves open areas of soil that can be taken over by fast-growing weed species. Diligent weed control measures are needed if this method of planting is used.

Bahiagrass can be established any time of year in much of Florida, but in north Florida, the best time to establish bahiagrass is during the spring or early summer months. This enables the grass to grow in before cooler weather begins, when growth is reduced. Seed may safely be sown until later in the year, but growth will again be reduced in the fall. When establishing any grass, it is important to irrigate more frequently and for shorter durations than usual. Until a viable root system is established, turfgrass planted from sod will have greater demands for water and irrigation is suggested if available. Multiple, short (5-10 minutes) irrigations throughout the course of the day for 7-10 days following planting helps the grass establish without drying out. For the next 7-10 days, irrigate once a day to apply $1 / 4-1 / 2$ inch of water. After this, frequency should be 
reduced to $2-3$ times weekly, again applying $1 / 4-1 / 2$ inch of water. Three to four weeks after sodding, the grass should be established and irrigation can begin on an as-needed basis. For more information, refer to ENH9, Watering Your Florida Lawn (https://edis.ifas.ufl.edu/lh025).

A newly planted lawn should not be fertilized until 30-60 days after planting. Because the root system is not developed on new plantings, fertilizing before this can result in nutrient leaching or runoff and potential pollution of ground or surface waters. Waiting to fertilize will not affect turf health or establishment. The lawn should not be mowed until the roots have had a chance to peg down into the soil, generally 14-21 days after planting. Pegging means that the sod cannot be lifted without appreciable force. For more information on preparing the site and establishment, refer to ENH03, Establishing Your Florida Lawn (https:// edis.ifas.ufl.edu/lh013).

Proper site preparation before planting is critical for successful establishment. Refer to ENH02, Preparing to Plant a Florida Lawn (https://edis.ifas.ufl.edu/lh012), for complete information on how to prepare the site for planting.

\section{Maintenance}

\section{Nutrition}

Proper nutrition is very important for sustaining a healthy lawn. Fertilization and other cultural practices influence the overall health and quality of the lawn and reduce its vulnerability to numerous stresses, including weeds, insects, and disease. It is very important that anyone fertilizing their lawn be familiar with and follow the Florida-Friendly Landscaping $^{\text {TM }}$ Best Management Practices (FFL BMPs). These practices are designed to maintain healthy lawns and reduce any potential nonpoint source pollution of water resources that might result from lawn and landscape fertilization and other cultural practices. There are now state and local regulations that cover lawn fertilization, so be aware of city and county guidelines and always follow the directions on the fertilizer bag. For more information on BMPs, please refer to ENH979, Homeowner Best Management Practices for the Home Lawn (https://edis.ifas.ufl.edu/ep236).

A soil test should be done to determine soil $\mathrm{pH}$ and what nutrients are available to the lawn. The local Extension office has instructions and supplies for taking soil samples and submitting them to the Extension Soil Testing Laboratory for analysis. Refer to http://soilslab.ifas.ufl.edu/ ESTL\%20Home.asp for more information on obtaining and submitting a soil sample. In particular, phosphorus levels are best determined by soil testing. Because some Florida soils are high in phosphorus, it may not always be necessary to always add phosphorus to a lawn once it is established.

Although the Florida Urban Turf Fertilization Rule (5E-1.003 F.A.C.; https://www.fdacs.gov/content/download/2911/file/UTR_Fact\%20Sheet.pdf) allows for application of up to $2 \mathrm{lb}$ of $\mathrm{N}$ per 1,000 square feet when applying fertilizer in the spring or summer and if using a fertilizer that has at least $65 \%$ controlled release nitrogen. Bahiagrass generally does not need this quantity of fertilizer. No more than $0.7 \mathrm{lb}$ of soluble (quick-release) $\mathrm{N}$ per 1,000 square feet can be applied at any one time (https://edis.ifas.ufl.edu/ ep353). However, there are exceptions to this rule in areas of Florida that have summertime fertilizer restrictions in place.

As a general rule, the first fertilizer application of the year should be early April in central Florida and mid-April in north Florida. In south Florida, fertilizer applications may be made throughout the year because growth is year-round. University of Florida guidelines for lawn grass fertilization offer a range of fertilizer rates over which a particular species may be successfully maintained in the various regions of the state. These ranges account for the effect that localized microclimates can have on turfgrass growth. A range of rates allows for these environmental variations. An example of this would be a typical home lawn that is partially shaded and partially sunny. The grass growing in the shade needs less fertilizer than that growing in full sun. Fertilization is also affected by soil type, organic matter in soils, and practices such as clipping management. Recycled clippings provide some nutrients back to the turfgrass and may reduce the need for fertilizer inputs. Additionally, a newly sodded lawn on a sand soil with no organic matter requires more fertilizer than a lawn that has been fertilized for many years. In Florida, new homes and new developments may be next to much older developed landscapes, and a one-size-fits-all approach to fertilization is not reasonable. Thus, the guidelines provide a base range from which the end user can begin a fertilization program. The homeowner is encouraged to initiate a program based on these guidelines and to adjust it over time based on how the turfgrass responds.

The fertilizer guidelines divide the state into three geographical locations as indicated in Table 1 . All rates are in pounds of nitrogen per 1,000 square feet per year. Depending on geographical location, fertilizer may be applied to bahiagrass in 1-3 applications from spring green-up through fall. Do not apply nitrogen too early in the growing season, particularly in north Florida, because late-season frosts may damage the grass. Likewise, do not fertilize too 
late in the year after growth has subsided. In south Florida, year-round fertilization is acceptable.

Table 1. Annual fertilization recommendations for bahiagrass in three regions of Florida.

\begin{tabular}{|l|c|}
\hline \multicolumn{1}{|c|}{ Location $^{\mathbf{1}}$} & $\begin{array}{c}\text { N fertility guideline } \\
\text { (Ib N/1000 sq ft/year) }\end{array}$ \\
\hline North Florida & $1-3$ \\
\hline Central Florida & $1-3$ \\
\hline South Florida & $1-4$ \\
\hline
\end{tabular}

${ }^{1}$ North Florida in this example is considered to be anything north of Ocala. Central Florida is defined as anything south of Ocala to a line extending from Vero Beach to Tampa. South Florida includes the remaining southern portion of the state.

Bahiagrass is susceptible to iron deficiency in high- $\mathrm{pH}$ $(>7.0)$ soils, which may result in yellowing of leaf blades. This can be overcome with the addition of an iron source. Soluble iron sources that can be used include ferrous ammonium sulfate, ferrous sulfate, and various iron chelates. Oxide forms of iron should be avoided because they are much less effective than sulfates or chelated forms in alleviating iron deficiency. Most granular iron sources are ineffective in Florida soils. Ferrous sulfate should be applied at the rate of 2 ounces in 3-5 gallons of water per 1,000 square feet. This can be applied evenly and easily with a hose-end applicator. Follow chelated iron label directions if using one of these materials. Iron applications every 6 weeks help maintain green color and, unlike nitrogen, do not promote excessive top growth. Keep in mind that a high-pH soil is not a good growing environment for bahiagrass and not an example of "right plant, right place."

Note that iron is not a substitute for nitrogen, which provides the building blocks for turfgrass growth and is required for turf health. While both iron and nitrogen deficiencies result in turfgrass yellowing, they are distinctly different deficiencies in plants. Applying iron does not cure yellowing due to nitrogen deficiency, and iron fertilizer is not a substitute for nitrogen fertilizer. Foliar iron fertilizers, such as iron sulfate or chelated iron solutions, help cure iron deficiencies, and nitrogen fertilizers applied according to BMPs cure nitrogen deficiencies.

\section{Mowing}

Proper mowing practices are necessary to keep any lawn healthy and attractive. During times of active growth, bahiagrass should be mowed with a rotary mower every 7-14 days to a height of 3-4 inches. The higher mowing height promotes a deeper, more extensive root system that makes the grass more stress tolerant. Do not remove more than $1 / 3$ of the height of the leaf blades at any one mowing (e.g., for a lawn to be maintained at 3 inches in height, turf should be mowed when it reaches $4-4 \frac{1}{2}$ inches). As bahiagrass does not grow extremely tall, mowing cycles are often dictated by seed head production. Clippings should be left on the ground after mowing. They do not contribute to thatch buildup, as is often assumed, but are actually readily degraded by microorganisms. They also provide a source of nutrients to the lawn and can reduce fertility requirements if regularly left on the lawn.

A sharp, heavy-duty rotary mower blade is needed to cut bahiagrass. Because bahiagrass leaves and seed head stems are very tough, the mower blade must be sharpened regularly to ensure a good, clean cut. If this is not done, the leaves may be torn by the mower blades, which can lead to disease or insect problems and leave the grass with a ragged appearance. For more information on mowing, please refer to ENH10, Mowing Your Florida Lawn (https://edis.ifas.ufl. edu/lh028).

\section{Watering}

Irrigating on an "as-needed" basis is the best way to water any established, mature grass, as long as the proper amount of water is applied when needed. Unlike some other warm-season grasses, bahiagrass can survive for extended periods without water, but it goes into a drought-induced dormancy, during which it turns brown and does not grow. To keep it green and growing, water is needed when leaf blades begin to fold up, wilt, or turn blue-gray in color, or when footprints remain visible after walking on the grass. Apply $1 / 2-3 / 4$ inch of water per application. This applies water to roughly the top 8 inches of soil where the majority of the roots are. Be sure to follow any local watering restrictions. Bahiagrass has the ability to generally recover from severe drought injury soon after receiving water from either rain or irrigation. If you do not have an irrigation system and see these symptoms, leave the grass alone through the drought period. Avoid mowing too low or applying fertilizer and pesticides. Bahiagrass should not be overwatered because this weakens the turf and encourages weeds. For further information on recommended watering practices, refer to ENH9, Watering Your Florida Lawn (https://edis. ifas.ufl.edu/lh025), and ENH63, Let Your Lawn Tell You When to Water (https://edis.ifas.ufl.edu/ep054).

\section{Pest Management}

Although bahiagrass is generally less troubled by insects, diseases, and nematodes than other Florida lawn grasses, it is still not completely pest free. Following are some of the major problems encountered in a bahiagrass lawn. 


\section{Weeds}

The best method of weed control is to maintain a healthy, vigorous turf. Following UF/IFAS recommendations for proper fertilization, irrigation, and mowing will help to maintain a healthy lawn that is able to outcompete most weeds. However, if weed problems persist, the following chemical treatments may be used on bahiagrass for weed control when needed.

Preemergence herbicides are used before a weed germinates and grows. These herbicides inhibit weed growth after germination. To effectively use preemergence herbicides, knowledge of what weed problems occur and where they occur in the lawn is necessary. This may take one or two years to determine. To control areas where crabgrass, sandbur, annual bluegrass, goosegrass, or crowfootgrass have been problems in previous years, benefin, bensulide, oryzalin, or prodiamine can be applied prior to their germination. Timing is important for successful control. As a general rule of thumb, preemergence controls should be applied around February 1 in south Florida, February 15 in central Florida, and March 1 in north Florida.

Postemergence herbicides are applied to weeds that are presently growing. Postemergence herbicides (e.g., 2,4-D, dicamba, and/or MCPP) should be applied in May as needed for control of annual and perennial broadleaf weeds, such as knotweed, spurge, and lespedeza. Selective control of emerged grass weeds, such as goosegrass, crabgrass, or alexandergrass, can only be achieved by hand pulling. Sedges can be controlled with applications of halosulfuron. Check with the local UF/IFAS Extension office for positive identification of weeds and exact herbicide recommendations. Apply herbicides only when adequate soil moisture is present, air temperatures are between $60^{\circ} \mathrm{F}$ and $85^{\circ} \mathrm{F}$, and the turf is not suffering from water or mowing stress. Failure to follow these precautions will result in damaged turf. For information on controlling weeds in the lawn, please refer to ENH884, Weed Management in Home Lawns (https://edis.ifas.ufl.edu/ep141).

Note: Many popular "weed-n-feed" fertilizers for home lawns contain the herbicide atrazine or metsulfuron. Both of these herbicides will damage bahiagrass; therefore, they are not recommended for use on this grass.

\section{Insects}

The most serious insect threat to bahiagrass is the mole cricket (Figure 3). These insects burrow though the soil and damage roots, causing the grass to wilt rapidly. Check for mole crickets by looking for their tunnels and mounds or by applying 2 gallons of water with 1-2 ounces of lemonscented dish detergent per 2 square feet of turf in suspected damaged areas. If present, the mole crickets will surface in a few minutes.

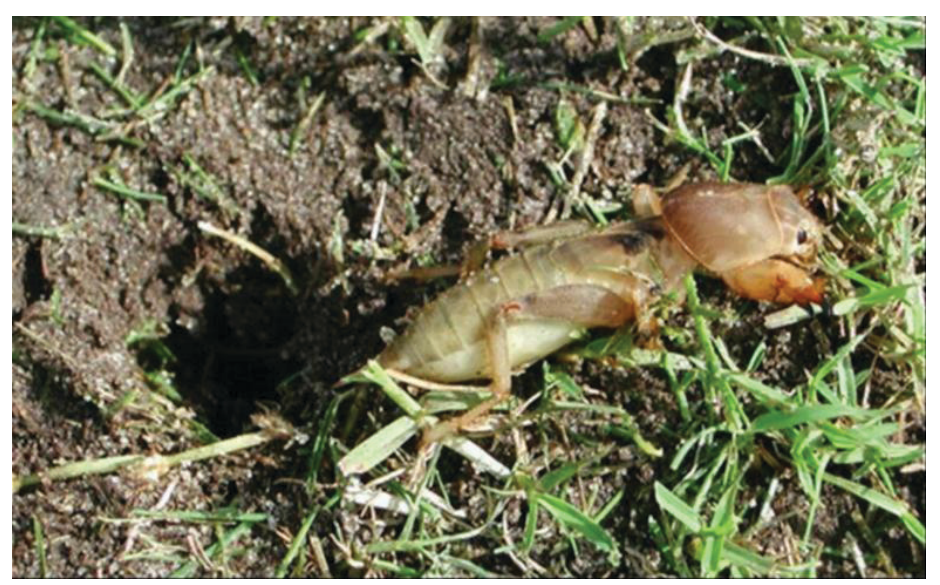

Figure 3. Mole cricket.

Credits: E. A. Buss, UF/IFAS

Bait-type insecticides have been introduced and show real promise as a control measure. However, insecticides available for mole crickets are constantly changing. For information on controlling insects in the lawn, please refer to CIR-427, Insect Management in Your Florida Lawn (https://edis.ifas.ufl.edu/lh034).

\section{Diseases}

Few diseases cause problems in bahiagrass, but dollar spot may sometimes be present. This is expressed as spots several inches in diameter scattered across the turf. A light application of nitrogen ( $1 / 2$ pound nitrogen per 1,000 square feet) should encourage the grass to outgrow these symptoms.

\section{Nematodes}

Nematodes are not typically as damaging to bahiagrass as they are to other lawn grass species. Because of bahiagrass's deep, extensive root system, nematode damage is seldom noticeable. However, if grass becomes thin, grows less vigorously, and develops a weak root system, nematode presence may be suspected. Soil samples may be sent to the Florida Nematode Assay Lab. For information, please refer to ENY-027, Nematode Assay Laboratory (https://edis.ifas. ufl.edu/sr011). Proper cultural factors to encourage bahiagrass root growth will lessen nematode stress. These include reducing nitrogen rates, watering less frequently but more deeply, and providing ample soil potassium. Please refer to ENY006, Nematode Management in Residential Lawns (https://edis.ifas.ufl.edu/ng039), for additional information. 